\section{Questión}

Periodismo / Comunicación ISSN 1669-6581

"Durante el macrismo, la radio canalizó un intento de resistencia cultural y política"

Marcelo Figueras - Viviana Vila

Question/Cuestión, Vol. 2, N 66, Agosto 2020

ISSN 1669-6581

https://perio.unlp.edu.ar/ojs/index.php/question/index

IICom-FPyCS-UNLP

\title{
“DURANTE EL MACRISMO, LA RADIO CANALIZÓ UN INTENTO DE RESISTENCIA CULTUAL Y POLÍTICA"
}

\section{"DURING MACRISMO, THE RADIO GROOVE AN ATTEMPT OF CULTUAL AND POLITICAL RESISTANCE"}

\section{Marcelo Figueras}

Director de Radio Provincia de Buenos Aires

Periodista y Escritor Twitter:@MarceloFigueras

\section{Entrevista sonora de Viviana Vila} Docente de la Facultad de Periodismo y Comunicación Social UNLP Locutora y Periodista de radio y televisión

Twitter:@viviana_vila 


\section{Resumen}

Viviana Vila entrevista al actual Director de Radio Provincia de Buenos Aires, Marcelo Figueras. Recorre la relación con la radio, caracteriza la actualidad del medio y describe la política que diseñó en contexto de pandemia.

\section{Palabras clave}

Radio, Institución, Pública, Programación

\section{Abstract}

Viviana Vila interviews the current Director of Radio Province of Buenos Aires, Marcelo Figueras. He goes through the relationship with the radio, characterize the news of the medium and describe the policy it designed in the context of a pandemic.

\section{Keywords}

Radio, Institution, Public

\section{Enlace}

https://go.ivoox.com/rf/55662679 